\title{
IKM DAN DIAGRAM KARTESIUS : KUALITAS PELAYANAN PDAM KOTA PONTIANAK PADA MASA PANDEMI COVID-19
}

\author{
Ana Yuliana ${ }^{1^{*}}$, Udin Rinaldi ${ }^{2}$ \\ Sekoah Tinggi Ilmu Ekonomi Indonesia Indonesia Pontianak ${ }^{12}$
}

\section{N F O A R T I K E L}

Riwayat Artikel:

Received : April, 20 2021

Revised : May, 30 2021

Accepted : June, $2^{\text {nd }} 2021$

\section{Keywords:}

quality of services, perception, the community satisfaction index, the new normal Covid-19 transition period

\section{Kata Kunci:}

kualitas layanan, persepsi, indek kepuasan masyarakat, masa transisi new normal Covid-19

\begin{abstract}
A B S T R A C T
The research aims to determine the community satisfaction index (IKM) regarding the service quality of PDAM Pontianak City including service standards carried out during the transition period for the new normal pandemic Covid-19 according to Pontianak Mayor Regulation Number 58 of 2020. The analysis tool uses the IKM analysis and Cartesian diagrams. The results of the study found that based on the IKM analysis, the indicators that were not optimal were the speed of service, service procedures and implementation schedule. Based on Cartesian analysis found major improvements in service procedures and clarity of officers, as well as additional improvements in the form of service speed, fairness of service costs and certainty of service schedules.
\end{abstract}

\begin{abstract}
A B S T R A K
Penelitian bertujuan untuk mengetahui indek kepuasan masyarakat (IKM) tentang kualitas pelayanan PDAM Kota Pontianak meliputi standart pelayanan yang dilakukan di masa transisi new normal pandemi Covid-19 sesuai Peraturan Walikota Pontianak Nomor 58 Tahun 2020. Metode penelitian deskripif kualitatif menggunakan data primer berupa 100 orang pelanggan yang diambil secara purposive. Indikator penelitian berdasarkan UU No. 25 tahun 2009. Alat analisis menggunakan analisis IKM dan diagram kartesius. Hasil penelitian menemukan bahwa berdasarkan IKM indikator yang belum optimal adalah kecepatan pelayanan, prosedur pelayanan dan jadwal pelaksanaan. Berdasarkan analisis kartesius ditemukan perbaikan utama pada prosedur pelayanan dan kejelasan petugas, serta perbaikan tambahan berupa kecepatan pelayanan, kewajaran biaya pelayanan dan kepastian jadwal pelayanan.
\end{abstract}

\footnotetext{
${ }^{*}$ Corresponding author:

Address : : Pontianak, Kalimantan Barat, Indonesia

E-mail : anayuana@gmail.com
} 


\section{PENDAHULUAN}

Sesuai dengan Peraturan Walikota Pontianak Nomor 58 Tahun 2020 Tentang Penerapan Disiplin Dan Penegakan Hukum Protokol Kesehatan Sebagai Upaya Pencegahan Dan Pengendalian Corona Virus Disease 2019. Pasal 8 menyebutkan bahwa Setiap orang, pemilik/pengelola tempat usaha dan transportasi serta pengelola, penyelenggara, penanggung jawab kegiatan, ASN dan Tenaga Kontrak atau sebutan lainnya, wajib melaksanakan dan mematuhi penerapan disiplin protokol kesehatan.

Selanjutnya pada pasal 8 point b menyebutkan, bagi pemilik/pengelola tempat usaha dan transportasi serta pengelola, penyelenggara, penanggung jawab kegiatan, wajib: 1) melakukan sosialisasi, edukasi dan penggunaan berbagai media informasi untuk memberikan pengertian dan pemahaman mengenai pencegahan dan pengendalian Covid-19; 2) melakukan pemeriksaan suhu tubuh di pintu masuk; 3) mengendalikan (mengawasi dan melarang) pengunjung dan karyawan yang tidak menggunakan masker ditempat usahanya; 4) menyediakan sarana cuci tangan yang memenuhi standar atau penyediaan cairan pembersih tangan (hand sanitizer); 5) melarang karyawan yang sakit untuk masuk kerja; 6) mengatur jarak meja dan tempat duduk serta antrian minimal 1,5 (satu koma lima) meter antar pelanggan; 7) membersihkan dan disinfeksi lingkungan secara berkala; 8) mengingatkan karyawan dan pelanggan untuk menerapkan protokol kesehatan Covid-19; 9) menjaga kebersihan tempat usaha/fasilitas umum; 10) memfasilitasi deteksi dini dalam penanganan kasus untuk mengantisipasi penyebaran -19;11) mengupayakan pembayaran secara non tunai (cashless); 12) menyiapkan petugas untuk mengawasi penerapan disiplin dan protokol kesehatan; dan 13) operator pelayaran dan operator bus wajib memastikan penumpang dengan hasil Rapid Test nonreaktif dan/atau Swab PCR Covid-19 negatif.

Sementara dalam kondisi yang normal, masih banyak penyelenggara pelayanan yang belum memberikan pelayanan sesuai dengan standar pelayanan sebagaimana amanat Pasal 15 huruf f UU No. 25 Tahun 2009 tentang Pelayanan Publik (UU Pelayanan Publik). Maka dalam kondisi saat ini diperlukan inovasi pelayanan oleh penyelenggara pelayanan salah satunya dengan memanfaatkan teknologi informasi (online) sehingga penyelenggaraan pelayanan tetap dapat berjalan efektif. Namun sayangnya tidak semua penyelenggaraan pelayanan dapat dilakukan secara online. Penanggung jawab penyelenggara pelayanan perlu melakukan identifikasi produk layanan yang dapat diberikan secara online dan secara manual (langsung) sehingga masyarakat dapat tetap mengakses pelayanan dalam kondisi saat ini.

Sebagaimana kita ketahui bersama bahwa ruang lingkup pelayanan yang sangat luas, termasuk di dalamnya adalah terkait pelayanan komunikasi dan informasi sebagaimana telah dijelaskan di atas. Maka pada kondisi pandemi Covid 19 ini pelayanan informasi menjadi penting, sehingga masyarakat mendapatkan pelayanan informasi yang memadai. Menurut Yulianto (2020) bahwa penyelenggara pelayanan perlu memberikan pelayanan informasi seluas-luasnya kepada masyarakat sebagai bentuk upaya memberikan perlindungan kesehatan kepada masyarakat dan menjaga stabilitas keamanan yang diakibatkan oleh informasi bohong (hoaks) sehingga menimbulkan kepanikan masyarakat yang berlebihan saat pandemi Covid 19.

Arus informasi yang sangat bebas diterima oleh masyarakat mengakibatkan masyarakat menjadi khawatir dan panik saat mendapatkan informasi yang tidak berimbang antara informasi yang relevan dan valid dengan informasi bohong (hoaks). Perlu dipastikan pelayanan informasi penanganan pandemi Covid 19 diberikan secara terstruktur, masif dan sistemik (Mungkasa, 2020). Misal terkait informasi perubahan standar pelayanan pada instansi penyelenggara pelayanan, informasi terkait wilayah penyebaran virus, dan lainnya. Sehingga masyarakat dapat menjalankan fungsi sebagai pengawas eksternal sebagaimana 
amanat Pasal 35 UU Pelayanan Publik, dalam hal ini adalah pelanggan pengguna jasa PDAM Kota Pontianak. Maka diharapkan dengan upaya bersama yang lakukan pada masa pandemi Covid 19 akan segera berakhir.

Salah satu dampak besar pandemi Covid-19 bagi masyarakat adalah bidang pelayanan. diperlukan penggunaan model integrasi vertikal dan horizontal dengan mengahadirkan network service layanan satu pintu yang membutuhkan transformasi pelayanan dari paradigma administrasi lama ke pelayanan yang baru. Selain itu, dibutuhkan juga harmoniasi antar lembaga pemerintah, agar tidak terjadi gesekan dan konflik yang berdampak pada penurunan kualitas pelayanan kepada masyarakat (Lumbanraja, 2020)

Menurut Keban (2010) bahwa semua kegiatan terlebih kegiatan yang berhubungan dengan jasa, selalu memastikan pelayanan yang diberikan adalah pelayanan yang terbaik, atau pelayanan yang prima, dari kondisi bangunan sarana dan prasarana kantor, sikap petugas, baik dari satpam sampai front office bahkan sampai office boy-pun tidak luput dari penilaian pelanggan. Perbaikan pelayanan dapat menjadi solusi dalam mengatasi krisis ekonomi yang berkepanjangan dengan cara memperbaiki investasi yang sangat diperlukan. Tetapi hal tersebut masih sebatas lips service. Menurut hasil studi pelayanan di Indonesia belum dimanfaatkan secara maksimal, sehinga hasil yang didapat pun tidak sesuai dengan apa yang diharapkan bahkan dampak negatiflah yang ditimbulkan. Akibatnya rencana menolong bangsa dari krisis ekonomi belum terrealisasi dengan baik sesuai yang diharapkan. Dampak lain yang ditimbulkan dalam kehidupan politik adalah lemahnya kepercayaan masyarakat terhadap pemerintah (Septiani dan Siswadhi, 2020).

Permasalahan yang dihadapi oleh PDAM Kota Pontianak ini sebenarnya lebih pada kesadaran masayarakat akan pentingnya mematuhi protokol kesehatan. Karena tidak jarang, masyarakat ini bertindak abai. Seperti: 1) Malas mencuci tangan meskipun sudah diarahkan ke area wastafel untuk mencuci tangan, 2) Saat menunggu panggilan sesuai antrian, terkadang tidak duduk di tempat yang sudah disediakan malah bergerombol sehingga menimbulkan kerumunan, 3) bahkan ada yang melepas masker (menurunkan masker ke dagu) saat menunggu di kursi tunggu dengan alasan tidak nyaman untuk bernapas. Namun kondisi tersebut dapat juga menjadi penghambat jika hal tersebut dijadikan resisten dalam pelayanan (Pinasti, 2020).

Kondisi saat ini menarik untuk dilakukannya survey kepuasan pelanggan khususnya pada Perusahaan Daerah Air Minum (PDAM) Kota Pontianak yang merupakan salah satu perusahaan yang bergerak dibidang jasa pelayanan. Oleh karena itu, penelitian ini ingin mengetahui bagaimana kepuasan masyarakat tentang kualitas pelayanan PDAM Kota Pontianak meliputi standart pelayanan yang dilakukan di masa pandemi Covid-19 serta permasalahan yang dihadapi.

\section{KAJIAN PUSTAKA}

\section{Kualitas Pelayanan dan Kepuasan}

Kualitas merupakan suatu kondisi dinamis yang berhubungan dengan produk, jasa, manusia, proses, dan lingkungan yang memenuhi atau melebihi harapan (Octavia 2019). Menurut Lewis dan Booms dalam Tjiptono (2011) kualitas merupakan merupakan ukuran seberapa bagus tingkat layanan yang diberikan mampu sesuai dengan keinginan pelanggan. Menurut Wijaya (2014) kualitas produk dan jasa didefinisikan sebagai keseluruhan gabungan karakteristik produk dan jasa yang dihasilkan dari pemasaran, rekayasa, produksi dan pemeliharaan yang membuat produk dan jasa tersebut dapat digunakan memenuhi harapan pelanggan atau konsumen. Osman \& Sentosa (2013) menyebutkan bahwa kualitas pelayan 
atau jasa merupakan keseluruhan karakter produk atau jasa yang dihasilkan untuk memenuhi kebutuhan pengguna layanan atau jasa dengan tujuan untuk memuaskan penggunanya.

Kotler dalam Tjiptono (2011), jasa adalah setiap tindakan atau perbuatan yang dapat ditawarkan oleh suatu pihak kepada pihak lain, yang pada dasarnya bersifat intangibles (tidak berwujud fisik) dan tidak menghasilkan kepemilikan sesuatu. Sedangkan menurut Alma (2010), jasa sebagai aktivitas, manfaat atau kepuasan yang ditawarkan untuk dijual. Supranto (2016) juga mendefinisikan jasa adalah Semua aktivitas ekonomi yang hasilnya tidak merupakan produk dalam bentuk fisik atau konstruksi, yang biasanya dikonsumsi pada saat yang sama dengan waktu yang dihasilkan dan memberikan nilai tambah (seperti misalnya kenyamanan, hiburan kesenangan atau kesehatan) atau pemecahan akan masalah yang dihadapi konsumen. Dapat kita simpulkan bahwa jasa merupakan aktivitas yang memiliki mamfaat atau kepuasan yang tidak berbentuk fisik dan dapat memenuhi kebutuhan konsumen yang menggunakanya.

Kualitas layanan merupakan sesuatu yang abstrak dan susah dipahami (Parasuraman dalam Astuti, 2014). Parasuraman mengembangkan sebuah instrumen analisa kualitas layanan, SERVQUAL, untuk mengukur kualitas layanan dalam suatu organisasi. Analisa ini dipercaya merupakan metode yang paling populer untuk meneliti kualitas layanan (Butt \& Cyril, 2010). Kualitas layanan yang baik merupakan hal yang penting untuk mencapai kesuksesan (Anggabrata, 2015), di mana kualitas layanan yang baik akan menyebabkan kepuasan pelanggan (Rosita, 2015), sehingga pada akhirnya akan mendorong loyalitas pelanggan, dan berakibat pada laba yang lebih tinggi.

Kepuasan pelanggan merupakan perbandingan antara apa yang diharapkan pelanggan (customer expectation) dengan apa yang diperoleh pelanggan (perceived quality) (Rahmawati, 2018). Kepuasan pelanggan juga dipengaruhi oleh persepsi nilai, yaitu evaluasi menyeluruh dari kegunaan suatu produk yang didasari oleh persepsi pelanggan terhadap sejumlah manfaat yang akan diterima dibandingkan dengan pengorbanan yang dilakukan (Baker \& Crompton, 2010). Selain itu, kepercayaan pelanggan juga dipercaya merupakan unsur yang mendasar bagi keberhasilan hubungan (Butt \& Cyril, 2010). Tanpa adanya kepercayaan suatu hubungan tidak akan bertahan dalam jangka waktu yang panjang. Dengan tercapainya kepuasan pelanggan dan kepercayaan, maka diharapkan akan tercapai loyalitas pelanggan untuk jangka panjang.

\section{Indiktor Kualitas Layanan dalam Industri Jasa}

Terdapat beberapa indikator kualitas pelayanan. Komitmen pelayanan jasa yang baik dalam upaya mempertahankan dan untuk meningkatkan mutu pelayanan yang berkualitas, maka suatu institusi atau organisasi harus melakukan pengukuran terhadap kualitas pelayanan yang telah disajikannya (Astuti, 2014). Tujuan pelayanan pada dasarnya adalah memuaskan pelanggannya (Dewi, 2016), untuk mencapai kepuasan itu dituntut kualitas pelayanan (Rosita, 2015).

Martin dalam bukunya yang berjudul "Managing Quality Customer Service" (Dewi, 2016) menyebutkan tujuh area standar yang digunakan dalam dimensi prosedural kualitas layanan adalah: Timing: Standar waktu yang ditetapkan perusahaan untuk menyajikan pelayanan kepada pelanggan, antara lain: 1)Flow: Komponen-komponen dalam penyampaian layanan harus dapat berkoordinasi dan bekerja sama satu sama lain serta menyampaikannya kepada pelanggan; 2)Accomodation: Kefleksibelan sistem yang diterapkan oleh perusahaan untuk diaplikasikan kepada permintaan konsumen yang beraneka ragam; 3)Anticipation: Perusahaan harus mampu mengantisipasi kebutuhan konsumen bahkan sebelum konsumen menyadarinya; 4)Communication: Membentuk 
komunikasi yang efektif dan efisien dari perusahaan kepada konsumen agar penyampaian layanan dapat optimal; 5)Customer feedback: Timbal balik dari konsumen sangat diperlukan untuk mengetahui bagaimana tingkat kepuasan konsumen terhadap pelayanan yang diberikan perusahan; 6)Organization dan supervision: Sebuah perusahaan memerlukan struktur organisasi yang baik dan optimal, serta melakukan supervisi dalam proses penyampaian layanan.

Selain itu terdapat tujuh area standar yang digunakan dalam dimensi personal kualitas layanan (Boulding at al, 1993 dalam Supartiningsih, 2017) adalah: 1)Appearance: Penampilan service person dalam menyampaikan layanannya kepada pelanggan; 2)Attitude: Bahasa tubuh dan intonasi yang digunakan dalam menyampaikan service ke konsumen. Hal ini meliputi kontak mata, senyuman, serta postur tubuh dan tangan; 3)Attentiveness: Memperhatikan setiap pelanggan pada kebutuhan dan keinginan mereka yang spesial dan unik; 4)Tact: Berkomunikasi dengan konsumen tidak hanya dalam hal menyampaikan pesan yang tepat ke konsumen, tetapi juga harus memperhatikan pemilihan kata-kata yang tepat; 5)Guidance: Konsumen memerlukan bantuan dari para pekerja baik seperti dalam hal memberikan saran dan bimbingan megenai layanan yang diberikan perusahaan; 6)Selling skills: Kemampuan menjual merupakan bagian layanan yang mengusahakan, memfasilitasi, dan meningkatkan penjualan yang harus dimiliki oleh seluruh staf; dan 7)Gracious problem solving: Komplain yang diberikan oleh konsumen harus ditanggapi dengan baik agar dapat mengembalikan kepuasan konsumen yang berkurang.

Cavana \& Corbett dalam Anggabarata (2015) menjabarkan konsep kualitas layanan jasa dalam 8 dimensi dengan atribut-atributnya sebagai berikut: 1)Assurance: Kesopanan petugas, pemberitahuan mengenai keterlambatan, keamanan personal, pengetahuan petugas dalam menjawab pertanyaan, mampu memberikan informasi mengenai perusahaan; 2)Empathy: Keramahan dalam memberikan keterangan, memahami kebutuhan konsumen, mengutamakan kebutuhan pelanggan; 3)Reliability: Menyediakan pelayanan yang on-time, memenuhi jadwal kereta yang telah dijanjikan, keterandalan dalam menangani masalah yang timbul, menyediakan pelayanan yang terbaik sejak pertama kali. 4)Responsiveness: Ketersediaan untuk membantu, layanan yang cepat dan tepat, ketersediaan staf untuk melayani permintaan pelanggan; 5)Tangible: Penampilan staf yang rapi dan professional, kejelasan informasi, kebersihan, penampilan yang modern, penampilan secara keseluruhan; 6)Comfort: Ketersediaan tempat duduk, kenyamanan tempat duduk, kenyamanan temperatur ruangan, kenyamanan selama proses; 7)Connection: Ketersediaan lapangan pakir, kemudahan akses, frekuensi waktu yang sesuai dengan kebutuhan; 8)Convenience: Kemudahan akses mengenai informasi, kemudahan akses, kenyamanan saat menunggu.

\section{Persepsi Nilai dan Kepuasan Pelanggan}

Gale (1997) dalam Rosita (2015) mengatakan bahwa tingkat loyalitas pelanggan dipengaruhi oleh persepsi konsumen terhadap nilai yang ditawarkan oleh perusahaan. Hasil dari sebuah evaluasi konsumen individual, terhadap suatu produk atau jasa dapat memenuhi harapannya atau mampu memuaskannya, maka di masa datang akan terjadi pembelian ulang. Osman \& Sentosa (2013), menyebutkan bahwa pelanggan membentuk suatu harapan terhadap nilai dan bertindak berdasarkan hal itu, dan mereka memperhitungkan atau mengevaluasi penawaran mana yang akan memberikan nilai tertinggi. Penawaran yang memenuhi harapan nilai pelanggan mempengaruhi kepuasan dan kemungkinan pelanggan membeli kembali. Rozi (2020), menyebutkan bahwa kepuasan pelanggan merupakan perbandingan antara kinerja yang diterima dengan ekspektasi, di mana kepuasan pelanggan bergantung pada persepsi nilai pelanggan itu sendiri. Membangun hubungan dengan 
pelanggan seringkali membawa keberhasilan, tetapi tidak selalu merupakan suatu strategi terbaik. Menurut Lovelock, Patterson dan Walker dalam Alma (2010), kesuksesan tersebut dipengaruhi oleh determinan, di antaranya kepercayaan, kepuasan terhadap produk dan jasa sebelumnya, dan persepsi terhadap nilai. Mosahab (2010) membuktikan adanya hubungan positif dan signifikan antara persepsi nilai dengan kepuasan pelanggan sesuai pendapat Butt \& Cyril (2010).

\section{Gap Pada Pelayanan Jasa}

Menurut Parasuraman at. al (dalam Supranto, 2016) ada lima gap yang memungkinkan kegagalan penyampaian jasa yaitu: 1) Gap antara harapan konsumen dan persepsi manajemen. Gap ini muncul apabila manajemen tidak merasakan atau mengetahui dengan tepat apa yang diinginkan oleh para pelanggannya; 2) Gap antara persepsi mana-jemen dan spesifikasi kualitas jasa. Gap ini bias terjadi apabila manajemen mungkin mampu merasakan atau mengetahui secara tepat apa yang dibutuhkan pelanggannya, tetapi tidak menyusun standar kerja yang harus dicapai; 3) Gap antara spesifikakasi kualitas penyampaian jasa. Hal ini bisa terjadi apabila standar-standar yang ditetapkan manajemen saling bertentangan sehingga tidak dapat dicapai. Misalnya karyawan diminta untuk harus meluangkan waktu mendengarkan keluhan pelanggan dan melayani mereka dengan cepat; 4) Gap antara penyampaian jasa dan komunikasi eksternal. Gap ini bisa terjadi apabila apa yang dikomunikasikan (dipromosikan) perusahaan kepada pihak luar berbeda dengan kondisi nyata yang dijumpai pelanggan pada perusahaan tersebut; dan 5) Gap antara jasa yang dipersepsikan dan jasa yang diharapkan. Gap ini terjadi apabila pelanggan mengukur kinerja perusahaan dengan cara yang berbeda dan salah dalam mempersepsikan kualitas jasa tersebut.

\section{Indeks Kepuasan Masyarakat}

Indeks Kepuasan Masyarakat (IKM) merupakan data dan informasi tentang tingkat kepuasan masyarakat yang diperoleh dari hasil pengukuran secara kuantitatif dan kualitatif atas pendapat masyarakat dalam memperoleh pelayanan dari aparatur penyelenggara pelayanan publik dengan membandingkan antara harapan dan kebutuhannya (Damayanti dkk, 2019).

Berdasarkan prinsip pelayanan sebagaimana telah ditetapkan dalam Keputusan Menpan Nomor: 63/KEP/M.PAN/7/2003, yang kemudian dikembangkan menjadi 14 unsur yang relevan, valid dan reliabel dalam Keputusan Menpan No. 25/M.PAN/2/2009 tentang pedoman umum penyusunan indeks kepuasan masyarakat unit pelayanan instansi pemerintahan. Sebagai unsur minimal yang harus ada untuk dasar pengukuran indeks kepuasan masyarakat adalah prosedur pelayanan, persyaratan, kejelasan petugas, disiplin petugas, tanggung jawab, kemampuan, kecepatan, keadilan, kesopanan, kewajaran biaya, kepastian biaya, penjadwalan, kenyamanan lingkungan, dan keamanan.

\section{Pandemi Covid-19}

Dikutip melalui internet (http://www.stoppneumonia.id/informasi-tentang-viruscorona-novel-coronavirus/) bahwa masa inkubasi virus corona 1-14 hari, virus berpotensi menyebabkan penyakit-penyakit fatal seperti Bronkitis dan Pnoumonia. Dan penyebaran virus ini bisa menular melalui udara baik yang kita hirup melalui hidung ataupun mulut. Ciriciri terkena Corona : Flu, batuk tak berdahak, demam dan infeksi radang tenggorokan dan bisa juga disertai di organ lainnya seperti Diare, sakit kepala, bersin-bersin, dan batuk. Virus Corona 2019-nCoV belum ada obatnya, beresiko menyebabkan kematian. Dikutip dari 
www.merdeka.com bahwa virus ini sudah menyebar ke beberapa negara seperti, Amerika Serikat , Perancis, Jepang, Korea Selatan, Taiwan, Singapura, Thailand, Australia, Nepal,Vietnam, Hongkong, Makau, Malaysia, Kanada dan pada saat ini sudah sampai ke Indonesia.

\section{Upaya Pencegahan Penyebaran Virus Corona}

1) Komunikasi

Agar dapat menghindari maupun mencegah krisis wabah virus corona tersebut, diperlukan upaya untuk menanggulanginya. Diantaranya adalah upaya-upaya yang dilakukan oleh pemerintah terhadap masyarakat dalam aspek komunikasi krisis. Menurut Coombs \& Sherry penulis buku Managing Corporate Social Responsibility: A Communication Approach (www.kompas.com) komunikasi krisis dapat di definisikan secara luas sebagai pengumpulan, pengelolaan, dan penyebaran informasi yang diperlukan untuk mengatasi suatu krisis. Maka dari itu, untuk mengatasi krisis yang dihadapi saat ini, pemerintah telah berupaya menyebarkan informasi untuk menanggulangi krisis wabah virus corona (-19) melalui media sosial maupun media massa.

2) Tim Gerak Cepat (TGC)

Dikutip dari www.kemlu.go.id upaya pemerintah dalam menanggulangi wabah virus corona diantaranya pemerintah telah membentuk dan mengaktifkan Tim Gerak Cepat (TGC) di wilayah otoritas pintu masuk negara di bandara/pelabuhan/Pos Lintas Batas Barat (PLBDN), melakukan pemeriksaan kesehatan di sekitar 135 titik di bandar udara, di darat dan pelabuhan, dengan menggunakan alat pemindai suhu tubuh bagi siapapun yang memasuki wilayah Indonesia. Selain itu kementerian kesehatan juga telah menunjuk sedikitnya 100 Rumah Sakit rujukan yang sebelumnya di pakai pada kasus flu burung, serta Kementerian Kesehatan membuka kontak layanan yang dapat di akses masyarakat untuk mencari informasi terkait wabah virus corona. Upaya-upaya tersebut dapat mencegah mewabahnya virus corona.

3) Pola Hidup Sehat

Di antaranya memulai hidup sehat, sering mencuci tangan memakai sabun, bila batuk atau pilek gunakan masker, perbanyak makan sayur dan buah, istirahat yang cukup dan rajin berolahraga, tidak mengonsumsi daging yang tidak dimasak, jika pilek, batuk hingga sesak nafas segera periksakan diri ke dokter (Pinasti, 2020).

4) Social descanting atau Social distance.

Social descanting atau social distance adalah masyarakat sebisa mungkin menghindari kerumunan orang - orang banyak seperti acara pertemuan, konser, pusat perbelanjaan, bioskop dan sebagainya yang memicu terjadinya kontak langsung atau bertatap muka. Selain itu, saat ini pemerintah mengimbau dan meminta masyarakat untuk melakukan aktivitas di dalam rumah saja seperti bekerja, belajar, maupun beribadah untuk menghentikan krisis wabah virus corona ini menyebar. Sosial descanting atau social distance ini bisa dikatakan upaya yang mudah dilakukan namun sulit dijalankan karena kurangnya kerja sama antara masyarakat itu sendiri (Zahrotunnimah, 2020).

5) Pembatasan Sosial Berskala Besar (PSBB)

PSBB merupakan pembatasan kegiatan tertentu penduduk dalam suatu wilayah yang sudah terinfeksi virus corona guna menekan angka penyebarannya. Kementrian Kesehatan melakukan pembatasan ini pada daerah tertentu, dengan tujuan yang lebih besar karena melihat kondisi lingkungan masing-masing (Zahrotunnimah, 2020). Misalnya korban cukup banyak, atau yang belum terkena tidak melaksanakan beberapa aturan yang berlaku (melanggar) sehingga mengganggu jalannya aktivitas penyembuhan. 


\section{Kerangka Pikir Penelitian}

Dalam penelitian ini dilatar belakangi oleh rendahnya kualitas pelayanan sektor pemerintah di kota Pontianak khususnya pelayanan PDAM Daerah Kota Pontianak. Pelayanan dinilai kurang baik pada penyaluran air bersih dan tidak merata untuk semua wilayah. Kebutuhan air yang utama oleh masyarakat khususnya pelaggan ketika musim kemarau, namun kualitas air yang diberikan kepada pelanggan terasa asin, hampir sama dengan air sungai. Selain itu masih ada beberapa tempat yang tersambug pipa atau pelangga tidak tersaluri air. Berdasarkan kondisi tersebut, ditambah dengan permasalahan pandemi Covid-19 saat ini, dimana Kota Pontianak masuk pada zona merah penyebaran Covid, sehingga pelayanan menjadi ekstra hati-hati. Kerangka pikir penelitian dapat kita lihat sebagai berikut :

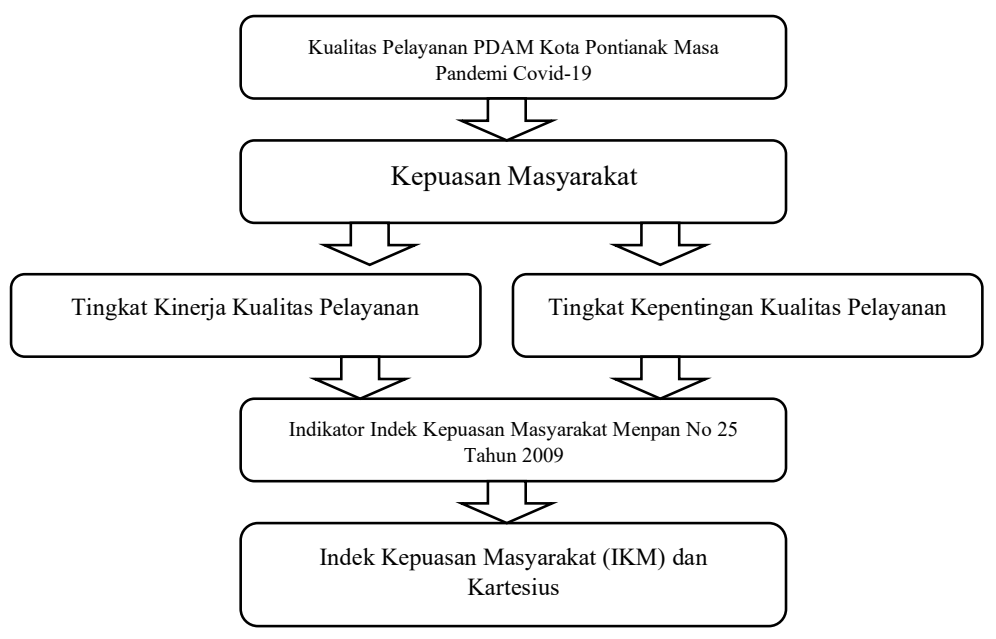

Gambar 1. Karangka pikir penelitian

\section{METODA PENELITIAN}

Penulisan menggunakan metode deskriptif analisis dengan melukiskan keadaan yang sebenarnya guna memperoleh fakta yang diolah menjadi data. Data kualitatif ditransformasikan menjadi data kuantitatif yang diolah lebih lanjut agar diperoleh suatu kesimpulan dengan obyek penelitian pada PDAM Kota Pontianak.

Penggunaan data primer melalui wawancara, kuisioner dan pengamatan langsung. Data sekunder diperoleh melalui dokumentasi dari perusahaan yang berhubungan dengan kualitas pelayanan PDAM Kota Pontianak pada kondisi pandemi Covid dengan memperhatikan Peraturan Walikota Pontianak Nomor 58 Tahun 2020 Tentang Penerapan Disiplin Dan Penegakan Hukum Protokol Kesehatan Sebagai Upaya Pencegahan Dan Pengendalian Corona Virus Disease 2019.

Populasi dalam penelitian ini adalah semua pengguna sambungan air ledeng atau pemilik rekening PDAM Kota Pontianak. Teknik pengambilan sampel dalam penelitian ini adalah secara purposive sampling yaitu pengambilan elemen-elemen yang dimasukkan dalam sampel dilakukan dengan sengaja dengan catatan bahwa sampel tersebut representatif. Agar Dalam hal ini penulis menetapkan responden terdiri dari 20 orang responden yang merupakan sambungan baru, kemudian 20 orang responden penggantian meteran, dan 20 orang responden pelanggan regular/biasa, selanjutnya 20 responden pelanggan bisnis/ ada usaha, dan 20 responden yang pernah melakukan klaim. Besarnya jumlah sampel penelitian, penulis menggunakan Teori Champion (Malo, 1986) dalam Umar (2013), yang menyatakan bahwa "Biasanya besarnya sampel tergantung kepada besar populasi yang hendak diteliti. Sekalipun sulit untuk menetapkan aturan besar sampel, 30 orang responden adalah jumlah 
minimal yang disebutkan para ahli metodologi penelitian, teristimewa jika penelitian menggunakan perhitungan statistik". Oleh karena itu, penulis menetapkan 100 orang responden sebagai sampel semua merupakan pemilik rekening sambungan PDAM Kota Pontianak.

Variabel penelitan yang mencakup kinerja mutu layanan dan harapan layanan atau tingkat kepentingan oleh pelanggan dengan dimensi variabel sesuai dengan indek kepuasan masyarakat keputusan Menpan nomor 25 tahun 2009, adalah sebagai berikut : 1)Prosedur pelayanan; 2)Persyaratan Pelayanan; 3)Kejelasan petugas pelayanan; 4)Kedisiplinan petugas pelayanan; 5)Tanggung jawab petugas pelayanan; 6)Kemampuan petugas pelayanan; 7)Kecepatan pelayanan; 8)Keadilan mendapatkan pelayanan; 9)Kesopanan dan keramahan petugas; 10)Kewajaran biaya pelayanan; 11)Kepastian biaya pelayanan; 12)Kepastian jadwal pelayanan; 13)Kenyamanan lingkungan; 14)Keamanan Pelayanan.

Teknik analisis menggunakan metode kualitatif yaitu data-data diperoleh dengan melihat jawaban dari responden melalui kuisioner yang telah disebarkan melalui wawancara. Kemudian jawaban dikelompokkan menurut kriteria yang ada. Hasil dari masing-masing jawaban dijumlahkan dan dikumpulkan dalam suatu tabel untuk dianalisis secara kuantitatif. Sementara secara kuantitatif adalah data-data berupa angka dianalisis dengan rumus tertentu dilanjutkan dengan metode Importance-Performance Analysis, IKM dan Analisis Kuadran.

\section{ANALISIS DAN PEMBAHASAN}

\section{Standart Pelayanan di Masa Transisi New Normal}

PDAM Kota Pontianak dengan nomenklatur baru mempunyai tugas pokok dan fungsi yang semakin berat. PDAM dituntut mampu melahirkan inovasi-inovasi terutama dalam melakukan penyelenggaraan pelayanan publik. Penyelenggaraan publik tidak bisa dilepaskan dari standar pelayanannya. Standar inilah yang kemudian menjadi tolok ukur pelayanan yang berfungsi sebagai pedoman penyelenggaraan pelayanan publik. Pedoman ini berfungsi sebagai acuan bagi pelaksana pelayanan publik dan para pengguna pelayanan dalam memenuhi dan memperoleh hak serta kebutuhan dasarnya. Standar pelayanan juga diperlukan dalam upaya menilai efektivitas pelayanan yang diberikan oleh PDAM Kota Pontianak serta mengukur kepuasan masyarakat saat mengakses pelayanan. Penilaian itulah yang kemudian bisa dijadikan landasan untuk memperbaiki kualitas pelayanan agar penyelenggaraannya semakin berkualitas, mudah, cepat, terjangkau dan terukur. Sekurangkurangnya Standar pelayanan tersebut wajib disusun, ditetapkan dan diterapkan sehingga diketahui oleh masyarakat luas yang mengakses pelayanan. Komponen wajib standar pelayanan yang harus ada pada unit manajemen pelayanan publik: Prosedur Pelayanan dan Jangka Waktu Layanan, adalah tata cara yang dibakukan oleh pemberi pelayanan terhadap penerima pelayanan publik. Prosedur pelayanan adalah proses yang harus dijalani seorang pelanggan untuk mendapatkan pelayanan yang diperlukan.

Pelayanan oleh PDAM dengan membuka pelayanan loket untuk memudahkan masyarakat Kota Pontianak yang hendak mengakses pelayanan perihal pelayanan pembayaran tagihan ledeng, pemasangan baru, pengaduan, dan lainnya. Pelayanan loket ini dapat ditemui oleh masyarakat di Perkantoran Terpadu atau Kantor Cabang Pembantu, Loket yang dikelola oleh mitra kerja serta Koperasi, khususnya disarankan menggunakan via online.

Sebelum adanya pandemi, pegawai pelayanan yang ditempatkan di masing-masing loket berkisar 3-6 orang. Namun sejak terjadinya pandemi -19 , pegawai yang bertugas di loket dikurangi separuh kapasitas dengan mematuhi standart protokol kesehatan yaitu physical distancing (jaga jarak). Dimana saat pandemi, pegawai yang melakukan pelayanan 
loket tagihan ledeng hanya ditugaskan 2 orang dari yang biasanya 4-5 orang. Pegawai di loket layanan pemasangan baru hanya 2 orang (1 pegawai melayani masyarakat dan 1 pegawai lainnya mengurus berkas) dari yang biasanya 3-4 orang. Begitupula dengan loket pengaduan, biasanya 2 orang sekarang hanya 1 orang. Para petugas loket diwajibkan menggunakan masker dan dibekali handsanitizer, begitu juga dengan pengunjung yang akan mengakses pelayanan di PDAM diatur dengan protokol kesehatan yang ketat. Selain itu, untuk pelayanan pengaduan dan konsultasi bisa melalui telpon atau bisa juga melalui WA kantor atau melalu email. PDAM dalam memberikan pelayanan terhadap masyarakat di masa transisi new normal saat ini sama seperti jam buka kantor yaitu Senin sampai dengan Kamis pukul 08.00-15.00 dan Jum'at pukul 07.30-10.30. Sesuai dengan Surat edaran Walikota Pontianak. Dengan mematuhi protokol kesehatan dan disiplin kerja, pegawai PDAM bekerja sesuai jam kantor untuk memberikan pelayanan terbaik bagi masyarakat. Pelayanan terbaik untuk masyarakat ini adalah wujud pemberian pelayanan prima kepada masyarakat. Untuk menunjang jalannya pelayanan yang baik, setiap pelayanan selalu ada mekanisme dan prosedurnya. Supaya masyarakat bisa memenuhi segala persyaratan yang dibutuhkan, dan pegawai di loket pelayanan juga bisa memproses dengan cepat. Ini adalah suatu bentuk simbiosis mutualisme antara pemberi layanan dan penerima layanan publik. Mekanisme pelayanan tersebut secara umum telah ada SOP-nya.

Pelayanan pada kondisi new normal setelah adanya pandemi, PDAM melakukan relaksasi SOP dimana ada beberapa aturan protokol kesehatan yang ketat yang harus dilalui oleh masyarakat yang datang di kantor. Masyarakat yang datang akan ditanya oleh satpam atau pegawai Tenaga Penunjang Operasinal Kantor (TPOK) untuk diarahkan. Biasanya masyarakat yang datang akan diberikan beberapa arahan sebagaimana berikut yaitu : 1) apa yang akan diurus, satpam akan memproses nomer antrian dan memberi arahan nantinya akan ke loket mana, akan diberi tahu juga untuk pembayaran tagihan disarankan via online melalui aplikasi untuk menghindari penumpukan. 2) masyarakat yang akan mengurus di cek suhu tubuhnya, 3) diarahkan untuk ke bilik sico dan cuci tangan menggunakan air mengalir di tempat yang sudah disediakan. Kemudian 4) diarahkan untuk duduk ke tempat duduk yang sudah disediakan dan diatur sesuai dengan protokol kesehatan.

Sarana, Prasarana atau Fasilitas. Kantor yang memberikan pelayanan harus didukung dengan sarana dan prasarana yang berkualitas serta memadai. Hal ini dilakukan supaya pengguna layanan yang datang ke PDAM Kota Pontianak merasa nyaman saat mengakses pelayanan. Itulah mengapa sarana dan prasarana termasuk dalam salah satu indikator standar manajemen pelayanan publik. Beberapa sarana dan prasarana yang telah disediakan antara lain : 1) Tempat Parkir yang luas dan bebas dari biaya parkir; 2) Ruang Tunggu; 3) Ruang Laktasi; 4) Zona bermain anak (playgrund); 5) Fasilitas difable (kursi roda, dan sebagainya); 6) Toilet; 7) Mobil e-pay dan tentunya ruang pelayanan yang nyaman berAC serta ditunjang dengan kesediaan komputer dan perlengkapan lainnya yang menunjang pelayanan.

Upaya mencapai visi dan misi yang didalamnya mempunyai manfaat bagi perusahaan dan pengguna jasa layanan PDAM Kota Pontianak dalam memberikan pelayanan yang sebaik mungkin bagi pelanggannya. Semua kegiatan yang dilakukan berorientasi pada kualitas pelayanan jasa sesuai peraturan Peraturan Walikota Pontianak Nomor 58 Tahun 2020 Tentang Penerapan Disiplin Dan Penegakan Hukum Protokol Kesehatan Sebagai Upaya Pencegahan Dan Pengendalian Corona Virus Disease 2019. Namun untuk menilai sekaligus mengevaluasi kegiatan perusahaan tersebut perlu dilakukan penelitian. Sesuai dengan permasalahan penelitian yaitu Bagaimana Persepsi Pelanggan Terhadap Kualitas Layanan PDAM di Kota Pontianak. 


\section{Indek Kepuasan Masyarakat (IKM)}

Evaluasi pelayanan dibedakan kedalam pelayanan tingkat kinerja dan tingkat harapan pelanggan dalam penelitian ini menggunakan 14 indikator pelayanan sesuai dengan indek kepuasan masyarakat (IKM) keputusan Menpan nomor 25 tahun 2009. Keputusan Menteri yang dianggap penting bagi masyarakat dalam menerima atau menggunakan layanan jasa pelayanan PDAM sebagai bentuk evaluasi kinerja yang telah dilakukan dihubungkan dengan kondisi lingkungan yang kurang menguntungkan disaat pandemi .

Berdasarkan hasil survei dan disesuaikan dengan IKM keputusan MENPAN nomor 25 tahun 2009, secara umum capaian kinerja PDAM Kota Pontianak untuk masing-masing dimensi variabel penelitian dapat dilihat pada Gambar 2 berikut :

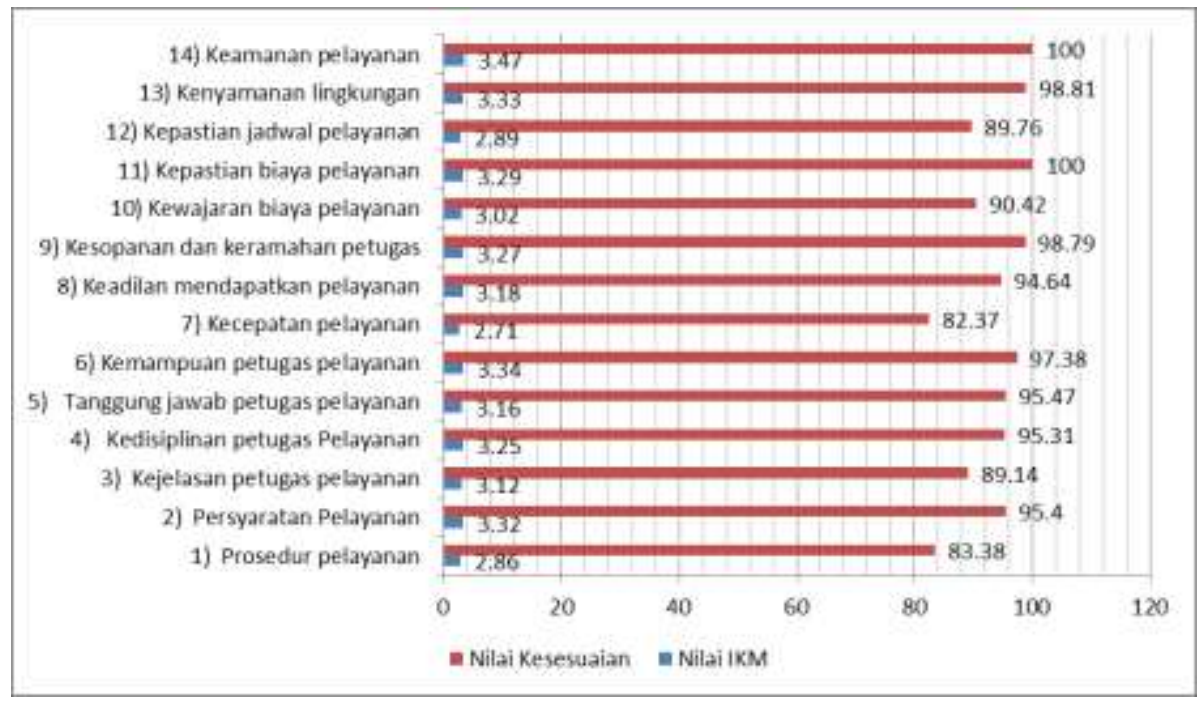

Gambar 2. Indikator berdasarkan Nilai Pelayanan (IKM) dan Tingkat Kesesuaian Sumber : Data olahan, 2020

Nilai IKM masing-masing unsur pelayanan pada PDAM Kota Pontianak secara umum evaluasi kinerja pelayanan adalah baik, namun beberapa unsur pelayanan memiliki nilai IKM yang menjadi prioritas perbaikan karena mendapatkan nilai kurang baik pelayanannya dari responden. Berikut merupakan unsur-unsur untuk perbaikan secara berturut-turut yang memiliki nilai terendah adalah: 1)Kecepatan pelayanan; 2)Prosedur pelayanan; dan 3)Kepastian jadwal pelaksanaan.

\section{Analisis Tingkat Kesesuaian}

Berdasarkan hasil penilaian tingkat kepentingan dan kinerja, maka akan dihasilkan suatu perhitungan mengenai tingkat kesesuaian antara tingkat kepentingan dan tingkat kinerjanya. Tingkat kesesuaian adalah hasil perbandingan skor kinerja pelaksanaan dengan skor kepentingan. Tingkat kesesuaian inilah akan menentukan urutan prioritas peningkatan faktor-faktor yang mempengaruhi kepuasan nasabah (Umar, 2013). Hasil pemetaan data tingkat kinerja perusahaan dan harapan pelanggan ditampilkan pada Gambar 2.

Berdasarkan data pada Gambar 2 dapat dijelaskan bahwa hampir seluruh indikator pelayanan yang diberikan perusahaan sudah baik dan sangat baik, namun masih berada dibawah nilai ekpektasi harapan pelanggan, diasumsikan bahwa pelayanan diberikan perusahaan yang berhubungan dengan indikator pelayanan dimasa pandemi masih belum memuaskan masyarakat tetapi mendekati keinginan. Artinya pelanggan menilai usaha pelayanan yang diberikan perusahaan perlu ditingkatkan dan masih dinyatakan kurang optimal. 
Berdasarkan data yang disusun menggunakan hasil perbandingan skor penilaian pelayanan dan skor penilaian kepentingan atau perhitungan tingkat kesesuaian bahwa tingkat kesesuaian variabel-variabel penelitian rata-rata sebesar $93,49 \%$, artinya nilai tingkat kesesuaian sudah sangat baik. Perbaikan hanya dilakukan pada kinerja yang nilai tingkat kesesuaian terendah dari nilai yang terbaik atau menggunakan urutan prioritas untuk memperbaiki/peningkatan mutu pelayanan. Semakin tinggi tingkat kesesuaiannya maka akan semakin baik. Nilai-nilai tingkat kesesuaian berdasarkan urutan prioritas tersebut antara lain pada variabel kecepatan pelayanan $(82,37 \%)$, prosedur pelayanan $(83,38 \%)$, kejelasan petugas pelayanan $(89,14 \%)$, kepastian jadwal pelayanan $(89,76 \%)$ dan kewajaran biaya pelayanan $(90,42 \%)$.

\section{Diagram Kartesius}

Hasil pengukuran variabel-variabel pelayanan memungkinkan perusahaan untuk dapat mengambil langkah/menitik beratkan usaha-usaha perbaikan untuk variabel-variabel penelitian yang dianggap kurang optimal di dalam pelaksanaannya. Berdasarkan data-data pada analisis tingkat kesesuaian antara kinerja perusahaan dan ekspektasi pelanggan dapat dipetakan pada diagram kartesius. Analisis kuadran atau juga disebut diagram kartesius merupakan sistem kordinat yang digunakan untuk meletakan titik pada penggambaran objek berdasarkan nilai tuas sumbu $\mathrm{x}$ dan nilai tuas sumbu y dimana titik pertemuan ini nilai sumbu $\mathrm{x}$ dan sumbu y untuk titik kordinat terbentuk yang selanjutnya dipetakan menjadi empat bagian, antara lain disebut area proritas utama (kuadran A), area pertahankan prestasi (kuadran B), area prioritas rendah (kuadran C), dan area prioritas berlebihan (kuadran D).

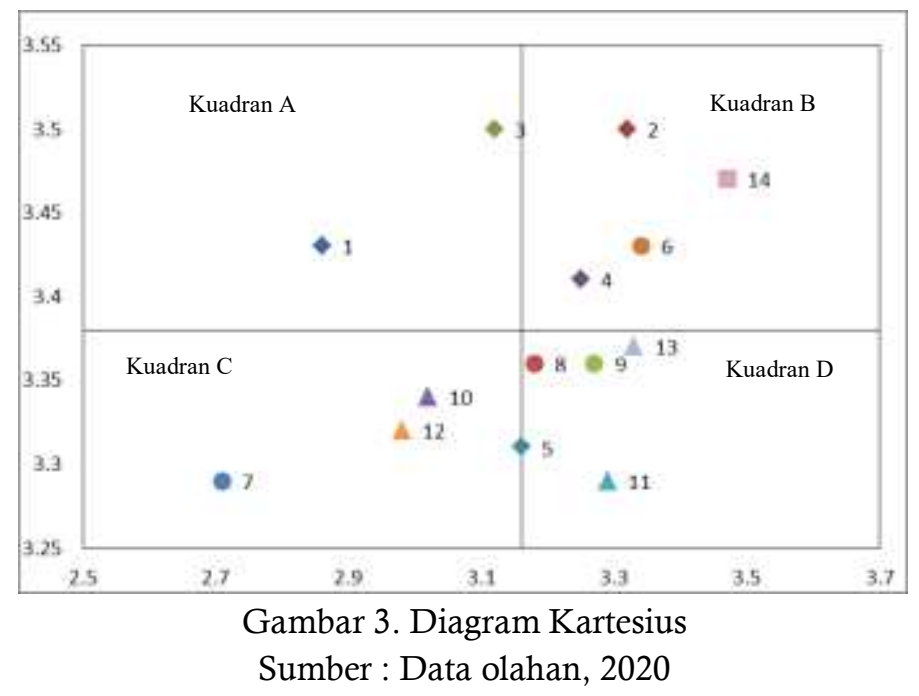

Kuadran A yang merupakan area prioritas utama, bahwa variabel penelitian dianggap penting, tetapi pelayanannya belum sesuai keinginan pelanggan. Oleh karena itu, perusahaan hendaknya melakukan usaha agar kepuasan pelanggan dapat diraih. Variabel yang termasuk dalam kuadran ini adalah prosedur pelayanan (1) dan kejelasan petugas pelayanan (3). Kuadran C yang merupakan area prioritas rendah, bahwa indikator penelitian yang dianggap kurang penting sehingga pelaksanaannya biasa-biasa saja sehingga kurang memuaskan pelanggan. Indikator termasuk dalam kuadran $\mathrm{C}$ adalah : Kecepatan pelayanan (7), Kewajaran biaya pelayanan (10), dan Kepastian jadwal pelayanan (12).

Kuadran B yang merupakan area pertahankan prestasi, bahwa posisi ini indikator penelitian yang dianggap penting dan pelaksanaanya sangat memuaskan pelanggan, maka harus dipertahankan oleh perusahaan. Indikator yang termasuk dalam kuadran B adalah : Persyaratan pelayanan (2), Kedisiplinan petugas Pelayanan (4), Kemampuan petugas 
pelayanan (6), dan Keamanan pelayanan (14). Kuadran D yang merupakan area prioritas berlebihan, bahwa indikator penelitian dianggap kurang penting, tetapi pelaksanaannya sangat baik, sehingga pelanggan merasa puas. Indikator termasuk dalam kuadran D adalah : tanggung jawab petugas pelayanan (5), keadilan mendapatkan pelayanan (8), kesopanan dan keramahan petugas (9), kepastian biaya pelayanan (11), dam kenyamanan lingkungan (13).

Berdasarkan diagram kartesius, menunjukkan posisi tiap indikator penelitian, yang dapat menjelaskan prioritas perbaikan atau dipertahankan bahkan ditingkatkan dengan strategi yang memadai. Kepuasan pelanggan adalah prioritas sehingga semakin tinggi nilai harapan yang diinginkan oleh pelanggan berarti semakin besar sumberdaya yang harus dikerahkan oleh perusahaan.

\section{SIMPULAN, KETERBATASAN DAN SARAN Simpulan}

Kualitas pelayanan yang diberikan oleh PDAM Kota Pontianak berdasarkan IKM keputusan Menpan nomor 25 tahun 2009 dengan 14 indikator pelayanan disesuaikan dengan Peraturan Walikota Pontianak Nomor 58 Tahun 2020 Tentang Penerapan Disiplin Dan Penegakan Hukum Protokol Kesehatan Sebagai Upaya Pencegahan Dan Pengendalian Corona Virus Disease 2019, secara umum berada dalam predikat baik.

Berdasarkan IKM dan diagram kartesius pada masa pandemi, posisi variabel penelitian atau indikator yang menjadi prioritas perbaikan utama sehingga menjadi perhatian untuk diperbaiki adalah indikator yang berada pada kuadran A antara lain prosedur pelayanan dan kejelasan petugas pelayanan. Sementara pada kuadran $\mathrm{C}$ merupkan indikator yang menjadi perhatian tambahan untuk diperbaiki terdiri dari indikator-indikator kecepatan pelayanan, kewajaran biaya pelayanan dan kepastian jadwal pelayanan.

\section{Saran}

Sebaiknya perusahaan lebih menekankan kecepatan proses dengan menyederhanakan proses pelayanan, memperbanyak petugas bagian pelayanan agar tidak terjadi penumpukan antrian (disesuaikan), peningkatan pelayanan harus berbasis kepentingan pelanggan dan mementingkan nilai-nilai kepedulian terhadap pelanggan.

Berdasarkan pemetaan diagram kartesius, prioritas perbaikan pada indikator penelitian yang berada pada kuadran A dan kuadran C, sehingga perusahaan sebaiknya melakukan halhal sebagai berikut : 1) Membentuk pelayanan mobile, artinya unit yang khusus melakukan tugas pelayanan kecelakaan sehingga keperluan pelanggan di lapangan dapat dilayanai dengan segera; 2) Meningkatkan kerjasama dengan instansi/perusahaan dan masyarakat dalam hal sosialisasi dan penyebaran informasi yang berhubungan dengan kemudahan dan lainnya; 3) Perusahaan sebaiknya meningkatan kualitas sumberdaya dengan pelatihanpelatihan atau CD-Room, dan penambahan tenaga kerja.

\section{DAFTAR PUSTAKA}

Alma B., (2010), Manajemen Pemasaran dan Pemasaran Jasa Edisi Revisi, Bandung: Penerbit Alfabet.

Anggabrata, Dewa Wisnu. (2015) Pengaruh Kualitas Pelayanan Terhadap Kepuasan Nasabah Pada PT. BPR Balidana Niaga Denpasar. E-Jurnal Manajemen Universitas Udayana. 4(5):98-114 May 2015.

Astuti, Eny Kustiah, (2014), Analisis Kepuasan Pasien rawat Inap atas Pelayanan Rumah Sakit Umum Kabupaten Sragen, Jurnal Gema, 8(2):48-52 Februari-Juli 2014 
Baker, D.A., and Crompton, J.L. (2010), Quality, satisfaction and behavioral intentions, Annals of Tourism Research, 27(3): 785-804.

Butt, M.M. and Cyril de Run, E. (2010). Private healthcare quality: applying a SERVQUAL model, International Journal of Health Care Quality Assurance, 23 (7) : 658-673.

Damayanti, Luh Dea., Suwena, Kadek Rai., \& Haris, Iyus Akhmad., (2019) Analisis Kepuasan Masyarakat Terhadap Pelayanan Publik Berdasarkan Indeks Kepuasan Masyarakat (IKM) Kantor Kecamatan Sawan Kabupaten Buleleng, Jurnal Pendidikan Ekonomi Undiksha, 11(1):21-32.

Dewi, Meutia, (2016), Pengaruh Kualitas Pelayanan Terhadap Kepuasan Pasien Pengguna BPJS Pada Rumah Sakit Rehabilitasi Medik Kabupaten Aceh Timur, Jurnal Manajemen dan Keuangan, 5(2): 535-544 November 2016.

Keban YT., (2010), Enam Dimensi Strategis Administrasi Publik: Konsep, Teori, dan Isu, Edisi Kedua. Cetakan Pertama. Yogyakarta: Penerbit Gaya Media.

Lumbanraja AD. (2020), Urgensi Transformasi Pelayanan Publik melalui E-Government Pada New Normal dan Reformasi Regulasi Birokrasi. Administrative Law \& Governance Journal, 3(2), 220-231.

Mungkasa O., (2020), Bekerja dari Rumah (Working From Home/WFH): Menuju Tatanan Baru Era Pandemi 19. The Indonesian Journal of Development Planning, 4(2), 126-150.

Mosahab, Mahamad, Ramayah. (2010) Service Quality, Customer Satisfaction, and Loyalty: A Test of Mediation, International Business Rese-arch, 3(04):72-80.

Octavia, Ria (2019) Pengaruh Kualitas Pelayanan Dan Kepuasan Nasabah Terhadap Loyalitas Nasabah PT. Bank Index Lampung, Jurnal Manajemen Pemasaran, 13(1):3542.

Osman, Zahir dan Sentosa, Ilham, (2013) Mediating Effect of Customer Satisfaction on Service Quality and Customer Loyalty Relationship in Malaysian Rural Tour. International Journal of Economics Business and Management Studies, 2(1):25-37.

Pinasti FDA., (2020), Analisis Dampak Pandemi Corona Virus Terhadap Tingkat Kesadaran Masyarakat dalam Penerapan Protokol Kesehatan, Jurnal Wellness And Healthy Magazine, 2(2), 237 - 249.

Rahmawati, Yulian Belinda. (2018) Pengaruh Kualitas Pelayanan Terhadap Kepuasan Nasabah Di PT. Bank Central Asia (BCA) Tbk Cabang Undaan Surabaya. Jurnal Fakultas Ekonomi Universitas Negeri Surabaya. 6(1):343-358.

Rosita, Rahmi (2015) Pengaruh Kualitas Pelayanan Terhadap Kepuasan Nasabah Bank Di Bekasi. Jurnal Lentera Bisnis Politeknik LP3I. 4(2):231-248.

Rozi, Ahmad Fathur dan Nasikan (2020) Pengaruh Kualitas Layanan, Citra Merek Dan Kepercayaan Terhadap Minat Beli Online Produk Batik Tulis Mutiara Sendang Lamongan, Jurnal Studi Manajemen dan Bisnis, 7(2):141-151.

Septiani E dan Siswadhi F., (2020), Pelayanan Publik Dalam Perspektif Administrasi Publik Di Indonesia, Syntax Literate (Jurnal Ilmiah Indonesia), 5(5), 55-67.

Supartiningsih, Solichah, (2017), Kualitas Pelayanan Kepuasan Pasien Rumah Sakit (Kasus Pada Pasien Rawat Jalan), Jurnal Medicoeticolegal dan Manajemen Rumah Sakit, 6(1):915 Januari 2017.

Supranto J., (2016), Pengukuran Tingkat Kepuasan Pelanggan untuk Menaikkan Pangsa Pasar, Cetakan Ketiga, Jakarta: PT.Rineka Cipta.

Tjiptono F., (2011), Strategi Pemasaran, Yogyakarta : Penerbit Andi.

------, (2016), Pemasaran Jasa, Cetakan Kedua, Malang: Penerbit Bayumedia Publishing.

Umar H., (2013), Metode Penelitian untuk Skripsi dan Tesis Bisnis, Jakarta: Penerbit PT Raja Grafindo Persada.

Wijaya T., (2014), Manajemen Kualitas Jasa, Cetakan ke-1, Kembangan-Jakarta. Barat : PT. Indeks 
Yulianto Y., (2020), Meningkatkan Kompetensi Aparatur Sipil Negara Dalam Pelayanan Publik Menuju Era New Normal. In Prosiding Seminar STIAMI, 7(2), 36-45.

Zahrotunnimah, (2020), Langkah Taktis Pemerintah Daerah Dalam Pencegahan Penyebaran Virus Corona Covid-19 di Indonesia, Jurnal SALAM (Jurnal Sosial \& Budaya Syar-i), 7(3), 247-260.

-------, Peraturan Walikota Pontianak Nomor 58 Tahun 2020 Tentang Penerapan Disiplin Dan Penegakan Hukum Protokol Kesehatan Sebagai Upaya Pencegahan Dan Pengendalian Corona Virus Disease 2019.

------, Menteri PANRB, Nomor Kep/25/M.PAN/2/2009 tanggal 24 Pebruari tentang pedoman umum penyusunan indeks kepuasan masyarakat unit pelayanan instansi pemerintahan.

Sumber Internet:

https://www.kemlu.go.id/portal/id

https://www.stoppneumonia.id/informasi-tentang-virus-corona-novel-coronavirus/

https://www.kompas.com/covid-19

https://www.merdeka.com/ 